Cronfa - Swansea University Open Access Repository

This is an author produced version of a paper published in :

Space and Culture

Cronfa URL for this paper:

http://cronfa.swan.ac.uk/Record/cronfa30515

\title{
Paper:
}

Chronopoulos, T. (2013). The Politics of Race and Class and the Changing Spatial Fortunes of the McCarren Pool in Brooklyn, New York, 1936-2010. Space and Culture, 16(1), 104-122.

http://dx.doi.org/10.1177/1206331212452364

This article is brought to you by Swansea University. Any person downloading material is agreeing to abide by the terms of the repository licence. Authors are personally responsible for adhering to publisher restrictions or conditions. When uploading content they are required to comply with their publisher agreement and the SHERPA RoMEO database to judge whether or not it is copyright safe to add this version of the paper to this repository. http://www.swansea.ac.uk/iss/researchsupport/cronfa-support/ 


\title{
The Politics of Race and Class and the Changing Spatial Fortunes of the McCarren Pool in Brooklyn, New York, 1936-20 I 0
}

\section{Themis Chronopoulos'}

\begin{abstract}
This paper explores the changing spatial properties of the McCarren Pool and connects them to the politics of race and class. The pool was a large liberal government project that sought to improve the leisure time of working class Brooklynites and between 1936 and the early 1970s it was a quasi-public functional space. In the 1970s and the early 1980s, the pool became a quasipublic dysfunctional space because the city government reduced its maintenance and staffing levels. Working class whites of the area engaged into neighborhood defense in order to prevent the influx of Latinos and African Americans into parts of Williamsburg and Greenpoint and this included the environs of the McCarren Pool. The pool was shut down in 1983 because of a mechanical failure. Its restoration did not take place because residents and storekeepers near the vicinity of the pool complained that by the 1970s, it was only African Americans and Latinos who patronized the pool and that their presence in the neighborhood undermined white exclusivity. For two decades, the McCarren Pool became a multi-use alternative space frequented by homeless people, graffiti artists, heroin users, teenagers, and drug dealers. Unlike previous decades, during this period, people of various racial and ethnic backgrounds frequented the pool area in a relatively harmonious manner. In the early part of the twenty-first century, a neoliberal city administration allowed a corporation to organize music concerts in the pool premises and promised to restore the facility into an operable swimming pool. The problem with this restoration project is that the history of the pool between the early 1970s and the early 2000s is downplayed and this does not serve well former or future users of the pool.
\end{abstract}

\section{Keywords}

McCarren Pool, Williamsburg, Greenpoint, Brooklyn, race, multi-use alternative space, historic preservation, place-making

In 2007, the Landmarks Preservation Commission of the City of New York decided that the McCarren Pool of Brooklyn was an architecturally and historically significant site and declared it a landmark (Horak, 2007). After this designation, the city administration decided to restore the McCarren Pool, which had been shut down since 1983. Built by Robert Moses in 1936 at the border of the Greenpoint and Williamsburg neighborhoods in northern Brooklyn, the McCarren

\footnotetext{
'University of East Anglia, Norwich, UK

Corresponding Author:

Themis Chronopoulos, School of American Studies, University of East Anglia, Norwich NR4 7TJ, UK.

Email:T.Chronopoulos@uea.ac.uk
} 
Pool was one of 11 immense Works Progress Administration (WPA) pools constructed in New York City (Gutman, 2007). In the decades that followed, the McCarren Pool served workingclass populations seeking inexpensive recreation. However, beginning in the early 1970s, the McCarren Pool became a contested site because the racial background of its users changed. Latinos and African Americans who had been moving in large numbers to parts of Brooklyn, started to use the pool. In reaction, the white ethnics of Greenpoint and Williamsburg discontinued their use of the pool and sought to undermine its existence. They eventually succeeded in shutting the pool down and keeping it inoperable for more than two decades. The debates that emerged after the pool's closure involved issues such as historic preservation, obsolescence, rebuilding, and racial exclusion.

What occurred in McCarren Pool was not unusual in the northeastern United States. As Jeff Wiltse (2007) has shown, African Americans who had been effectively excluded from public pools in the first half of the 20th century unleashed a number of legal and social challenges against discriminating authorities in the 1950s and the 1960s. However, their victories did not translate into interracial swimming as white swimmers abandoned public pools for private ones. In McCarren Pool, minority populations were not banned because of official regulations but because of geography. Moses built the McCarren Pool on the border of Williamsburg and Greenpoint because the people who lived there were white. Moses avoided building pools in racially diverse areas because he believed that racial mixing in pools was dangerous (Caro, 1974).

In his studies of world cities, Anthony M. Tung (2001) has been troubled by the fact that the preservation of historic sites is antithetical to the well-being of their less well-off users; while this is usually the case, the debates regarding the historic preservation of the McCarren Pool reveal a story that is more complicated. Many of the original proponents of the historic preservation of the McCarren Pool felt that the granting of landmark status was the only way to guarantee the reopening of a racially inclusive site. Local white ethnics and their elected representatives rallied against the historic preservation of the structure and proposed its replacement with a more limited and exclusive site. They managed to derail the designation of the McCarren Pool as a historical landmark in 1990 while claiming that the politics of race had nothing to do with their desire to reduce the size of the pool by three-fourths (Gilbert, 2007a, 2007b).

In recent years, the city administration has promoted the restoration of the McCarren Pool and its potential reopening in 2012 as an achievement of Mayor Michael Bloomberg and his environmentally shrewd vision (Partnerships for Parks, 2007); what is absent from this account is a history of the McCarren Pool that includes the racial injustices that surrounded it. Although upbeat, the sanitized historical version that has been advanced is inaccurate and does not serve well former or future users of the pool. As Dolores Hayden (1995) has proposed, there is a need for a new public history so that urban landscapes can adequately reflect the diverse manifestations of ordinary people in time and space. Once it reopens, users of the McCarren Pool should be aware of a more comprehensive history of the site rather than accept a version that emphasizes its purported "golden era" between the 1930s and the 1960s as if nothing significant happened in the four decades that followed.

\section{From Functional Quasi-Public Space to Source of Social Conflict}

Once in operation in the late 1930s, the McCarren Pool became a source of pride for Greenpoint and Williamsburg residents (Marcus, 2006). Having no access to most of their waterfront, which had been taken over by private industry and knowing that the city's rivers and oceans had become liquid wastelands because of industrial pollution and ocean dumping (Melosi, 1981), local residents found that the McCarren Pool was the only proximate place where they could swim in the summer. Just like the other WPA pools, the McCarren Pool provided three distinct 


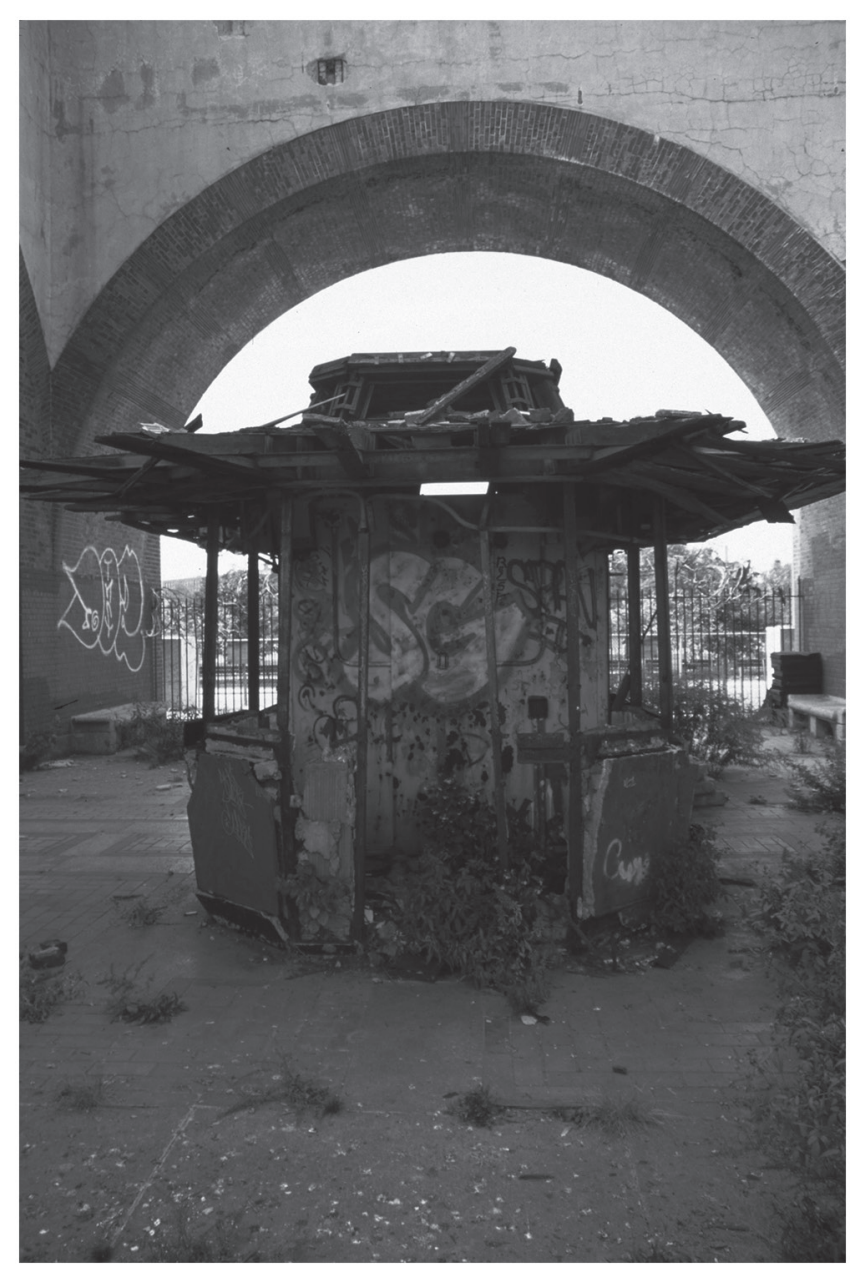

Figure I. The old ticket booth (2002).

Source: Author.

pools; the main one, which was for swimming; a deeper pool, which was for diving; and a shallow pool, which was for wading. To enter the pool (Figure 1), those younger than 14 years had to pay 10 cents and those 14 years or older had to pay 20 cents, fees that Robert Moses set because free access went against his sensibilities. Besides serving people seeking to bathe in the summer, the pool also became the home of annual swimming competitions, aquatic exhibitions, and children's shows. In the winter months, the pool facilities functioned as a gym and a dance hall (Marcus, 2006).

Between 1936 and the early 1970s, the McCarren Pool was a functional quasi-public space. The Department of Parks and Recreation operated the pool seasonally, set its hours of operation, maintained its infrastructure, established admission and conduct rules, enforced those rules, overlooked the safety of users, and secured the pool with guards and fences. The way that the pool operated, resembles Jerold Kayden's conceptualization of privately-owned public spaces such as hotel lobbies, retail stores, and museums where the public is welcome, but owners set the 
rules and users must conform to them (Kayden, 2000). In this case, the pool was not private, but it was regulated by the city government the way that private owners regulate their own quasipublic spaces. The operation of the pool as a quasi-public space regulated by the authorities, also relates to Michel de Certeau's concept of a property city where every spatial use is planned by technocrats and allocated into its proper place (de Certeau, 1984). Indeed, almost everything that happened inside the pool was subject to the wishes of the planners. Moses designed the premises so that all patrons were subjected to the same stages of progression before entering the pool. This progression started in the admission booth and continued in successive stages in locker rooms, toilets, shower rooms, and foot-bath areas. Men and women had to separate after the admission booth, though they could mix again after the foot-bath areas (Marcus, 2006).

Up until the early 1970s, the McCarren Pool remained a functional quasi-public space. Functional because the city government adequately maintained, repaired, and staffed the pool. Quasi-public because users were required to conform with regulations established by the parks department. Users could be ejected from the pool or denied entry, if pool employees felt that they did not conform with these regulations.

In the post-World War II period, the racial dynamics of Greenpoint-Williamsburg shifted and this generated antagonism among groups of people divided by race. Puerto Ricans and African Americans began to move to Brooklyn in great numbers. Hostilities among whites and nonwhites centered on neighborhood territory and were exemplified by battles about housing as well as transportation and public facilities (Wilder, 2000; Susser, 1982). The McCarren Pool, which represented one of the most prized quasi-public facilities in the area, became the object and source of social conflict among people of different racial backgrounds.

By 1969, the racial and ethnic geography of Greenpoint-Williamsburg was imagined in the following terms (Figure 2). Northern and central Greenpoint were overwhelmingly Polish with some Italians and Irish living there. The area between Monsignor McGolnick Park and the Grand Street subway station was mostly Italian. The Northside of Williamsburg was Russian, Ukrainian, and Polish with a few other eastern and southern Europeans also living there. South of Grand Street or Metropolitan Avenue, the population was largely Puerto Rican and growing. The southwest side of Williamsburg south of the Williamsburg Bridge was orthodox Jewish. The areas immediately north of Bedford-Stuyvesant and Bushwick were African American and Puerto Rican. Bedford Stuyvesant was becoming the city's largest Black neighborhood whereas Bushwick was becoming predominantly Puerto Rican. Almost all the waterfront was occupied by private industry and public corporations (New York City Planning Commission, 1969).

White ethnics felt that they had to protect the areas around subway stations because otherwise their access to Manhattan would be severely limited and the commercial centers adjacent to them would fail (Figure 2). The areas around stations of the LL train (renamed to L in 1985) became the most important because this subway line went quickly to 14th Street in Manhattan and connected with other subway lines going to most parts of the city. White ethnics defended the areas around the Bedford Avenue, Lorimer Street, Graham Avenue, and Grand Street subway stops. The area around the Graham Avenue stop was the most important because it was surrounded by the largest Italian commercial center of Williamsburg-Greenpoint and the most contested because of the presence of the Cooper Park Houses nearby - a public housing complex that was completed in 1953 and housed 700 families, most of which gradually changed to African American and Latino. Some minority residents of the Cooper Park Houses preferred to walk to the more distant Grand Street stop to avoid confrontations, though this route was also dangerous since it was longer and went through Italian blocks. At the same time, Kingsland Avenue, which represented a direct walking route from parts of Greenpoint to the Graham Avenue subway stop became dangerous for white ethnics because it passed through the front of the Cooper Park Houses (Ethnographic Research, 1996-1998). ${ }^{1}$ 


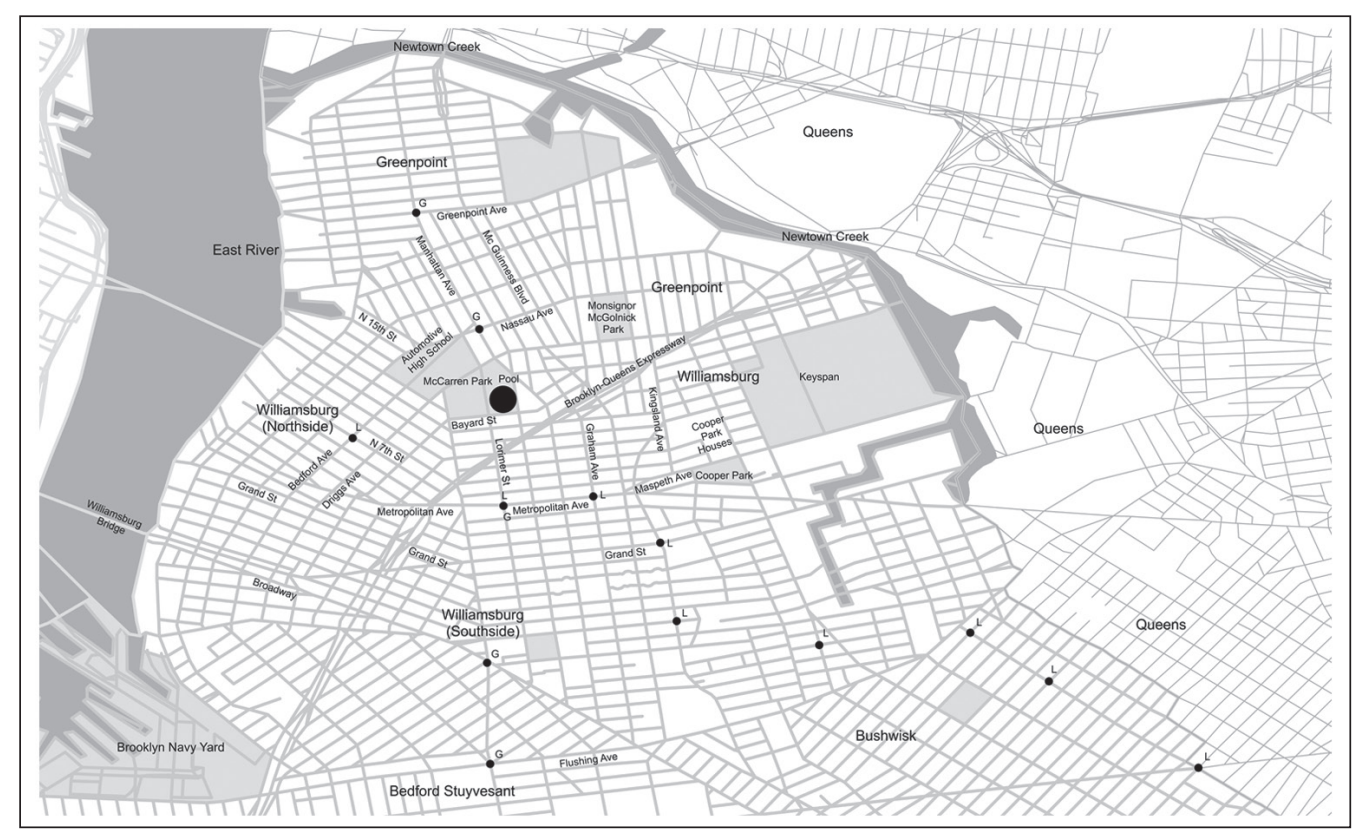

Figure 2. Map of Williamsburg-Greenpoint.

Source: Author.

As the numbers of Latinos and African Americans in the area increased (New York City Bureau of Health Statistics and Analysis, 1974), the location of the McCarren Pool undermined many of these white neighborhood defense efforts. In the 1970s, Puerto Ricans and African Americans walked in large numbers toward the pool from their homes in locations south of Metropolitan Avenue as well as from bus stops and subway stations. Bedford and Driggs Avenues, which were the two main thoroughfares of the Northside were overrun by Puerto Ricans who walked in groups so that they could prevent attacks by whites. So were areas directly south of the pool. Some Puerto Ricans from Bushwick took the LL train whereas some African Americans from Bedford-Stuyvesant took the GG train (later renamed to G) to travel to the pool. Most of these commuters exited on the Lorimer Street-Metropolitan Avenue stops and walked to the pool. However, some of them took the GG train all the way to Nassau Avenue, which was the closest subway stop to the pool. Manhattan Avenue between Nassau Avenue and Greenpoint Avenue was the main commercial center of Greenpoint, dominated by Polish and Italian people. This commercial center spilled over to Nassau Avenue especially between Manhattan Avenue and McGuiness Boulevard (Ethnographic Research, 1996-1998).

Many whites in Greenpoint were resentful about the movement of minorities from areas south of Metropolitan Avenue northward even if temporarily to use the pool; however, the numbers of Latinos and African Americans walking toward McCarren Park were too large and neighborhood defense was not possible. To the dismay of Northside residents, many people from Greenpoint were even giving up on Bedford Avenue, which used to be a major commercial center, but began to languish in the 1970s. In the summer months, many people from Greenpoint avoided the LL stop of Bedford Avenue, because there were so many non-whites frequenting that vicinity. The McCarren Park was also viewed as a lost cause, because many minorities walked through it on their way to the pool. What some ethnics in Greenpoint could not tolerate was Puerto Ricans and African Americans walking around the sidewalks of Manhattan and Nassau Avenues. When the 
school year was over and the weather got very hot, hundreds of non-whites could be seen near the Manhattan-Nassau commercial center on their way to and from the pool. They were taunted and attacked by whites, but the confrontations interfered with commerce and did not dissuade minorities from going there. In other words, the existence of the McCarren Pool undermined the whiteness of sizable sections of Williamsburg and Greenpoint, transformed subway stations into racially mixed spaces, and even affected the commercial center of Greenpoint (Ethnographic Research, 1996-1998).

During this period, many white ethnics in Greenpoint and Williamsburg concluded that the McCarren Pool should be closed, since local people were no longer using it, and "undesirable" elements from other areas invaded their neighborhood to use it. They defined "undesirable" elements as low-income Latinos and African Americans. The words used by whites to characterize these "undesirables" were "people on welfare," unruly teenagers," "dangerous males," "shoplifters," and "criminals." They also used many racial insults. Although the majority of the people frequenting the pool were women and their children, most whites described teenage and adult males of color as the individuals creating problems (Ethnographic Research 19961998 and 2002).

Whatever the case, the presence of the McCarren Pool undermined white neighborhood defense in the 1970s and early 1980s. Italians from the Graham Avenue vicinity claimed that they used to think that they were "holding the line [of defense]" on Grand Street with the only exception being the Cooper Park Houses. Then they realized that Latinos and Blacks were penetrating the neighborhood from behind their lines of defense on their way to the pool. Efforts to defend the Lorimer Street and Metropolitan Avenue subway stops proved to be futile in the summer. Polish people also concluded that Greenpoint was not as safe from minority invasions as they used to think (Ethnographic Research, 1996-1998).

\section{The McCarren Pool as a Dysfunctional Quasi-Public Space}

By the late 1970s, it was obvious that New York's 38.5 square mile park system had fallen into grievous disrepair (Davis, 1978). Parks officials admitted that only $26 \%$ of the city's parks and playgrounds could be found in a decent state and Parks Commissioner Gordon J. Davis claimed that he did not even know whether he would have enough employees the following day to collect the garbage from all the parks. Indeed the number of parks employees had been steadily declining. In the 1930s, Parks Commissioner Robert Moses had about 30,000 parks employees at his disposal. In 1980, there were 2,779 permanent workers and 1,458 temporary ones who could not find any other jobs and were hired under the federal Comprehensive Employment and Training Act for 18 months. In addition to the small workforce, the parks department lacked functioning equipment, could not coordinate garbage pickups, and was postponing many tasks because of planned renovations (Davis, 1979; Quindlen, 1980; Goodwin, 1980).

Although the fiscal crisis of the City of New York in 1975 forced the city administration to make substantial cuts in municipal services, the city's public infrastructure had not been adequately maintained for most of the postwar period. A series of mayors understood that they could not politically benefit from maintaining existing facilities, so they focused on the construction of new ones. Elected officials also realized that deferred maintenance helped them balance budgets and defer the day of reckoning to the distant future. In the 1970s, the city's public infrastructure reached the breaking point because of chronic neglect. However, the city government had no money to repair most of this infrastructure and at a time that highways and bridges were on the brink of collapse, the repair of public parks was postponed even more. Individuals who used the pool in the 1970s remembered a steady decline. Some days the pool did not open because of mechanical problems. In the beginning of some seasons, the pool opened late because its 
employees could not make everything work on opening day. The number of employees kept on decreasing, many showers became inoperable, the foot-baths stopped functioning, and garbage floated in the water. The chlorination system of the pool was frequently malfunctioning and many children began to get skin rashes. Complaints forced the parks department to remedy problems through a patchwork of temporary solutions. Almost all of the pool employees were white though almost all of the pool users were Latino and African American. As the numbers of employees declined, they had difficulties disciplining the large number of users. Sometimes, employees called the police, but the police department was also overextended and frequently police officers did not even show up. During off-hours, many young people entered the pool area and vandalized it. However, parks employees were slow to repair the fences and the local police did not seem to care about trespassers (Yampolsky, 1989; Ethnographic Research, 1996-1998).

Many whites who wanted the pool closed, argued that it had been taken over by prostitutes and criminals (Brozan, 1990). In the 1990s, people of various racial and ethnic backgrounds interviewed for this project argued that the pool attracted a criminal element, though claims that they dominated the pool were exaggerated. Greenpoint and the Northside had their own white gangs, which also frequented the vicinity of the pool trying to sell narcotics and stolen goods. Sometimes, these gangs would clash with African American or Latino ones, but most of the criminal activity and battles took place in areas away from the pool. Women who used the facility during this period said that on their way to the pool, young whites insulted them with racial and sexual epithets. The perception that the pool had been taken over by prostitutes was constructed and reinforced by local whites. This discourse helped to further delegitimize pool users and cultivate a climate of hostility against them (Ethnographic Research, 1996-1998).

\section{Debates Over the Restoration of the McCarren Pool}

The McCarren Pool closed after the summer of 1983 and plans to reconstruct it did not materialize. Accidental flooding of the filter plant, boiler room, and mechanical systems made the pool inoperable. The Department of Parks and Recreation had already decided in 1979 to rehabilitate the McCarren Pool in its entirety. This was part of a $\$ 100$ million plan to reconstruct all the WPA pools, which had been neglected for many years (Davis, 1980a, 1980b). However, the \$6.5 million reconstruction plan of the McCarren Pool never occurred. Throughout 1984, white residents of Greenpoint and the Northside voiced their opposition against the restoration of the pool with demonstrations and meetings. When contractors showed up to survey the pool, demonstrators made them leave (Marcus, 2006; Stern, 1985a, 1989). After the unsuccessful attempt by the city government to restore the McCarren Pool, the debate reverted to the local community board. The City of New York is subdivided into 59 community districts with their own community boards, which are local representative bodies. Their members are appointed by the borough president and act as advocates for the community. The decisions of community boards are nonbinding, though the city government may take them into consideration. Brooklyn's Community District 1 encompasses Greenpoint and Williamsburg. The pool issue was debated in a raucous meeting in the spring of 1985. In that meeting many whites proposed that the pool should be demolished because members of the surrounding community no longer used it and because it attracted outsiders of questionable character. They wanted a soccer field instead. Blacks and Latinos insisted on restoring the existing pool in its entirety. Some whites suggested that a smaller pool be built as a compromise. The Department of Parks and Recreation had already been reducing the size of some other WPA pools, drawing the ire of preservationists and elected officials (Stern, 1985b, 1985c). Nonetheless, it was suggested that the size of the pool should be reduced, since 6,800 pool users were too many. The city government presented the community board with various reconstruction alternatives and after months 
of deliberations, in April 1986, Community Board 1 voted to demolish most of the pool's installations and replace them with an Olympic-sized pool, one-fourth the size of the existing pool, a new gymnasium, and three basketball courts (Celona, 1986; Mendell, 1986).

Discussions between the parks department, community board members, and Friends of McCarren Park - a local organization that advocated the welfare of the park-continued. In May of 1987, these entities met and decided on more specific plans for the reconstruction of the McCarren Pool. The basketball courts disappeared from the new plans. In that meeting, parks officials claimed that the reconstruction would begin in 1992 (Friends of McCarren Park, 1987). Local community board members and elected officials found the wait for the restoration to be too long. They lobbied for the earlier reconstruction of the pool and requested the immediate demolition of the existing structure because it had been taken over by "unsavory" characters. Parks officials responded that existing policy prevented them from demolishing abandoned facilities until their replacement was ready for construction. In May 1988, Community Board 1 and all the local elected officials voted unanimously to approve a plan by the parks department, which called for the preservation of the central arch and adjacent archways of the structure and the demolition of the existing low-ceilinged wings emanating from the archway. The main feature of the restored structure would be the new smaller pool while a new gymnasium would be erected behind the north wing of the pool. The demolition-reconstruction would begin in the summer of 1989 (Braiterman, 1989; Stern, 1989).

In the fall of 1988, members of the Friends of McCarren Park, the organization that had been instrumental in coming to the restoration compromise of a few months before, began to reconsider the idea of demolition. Phyllis Yampolsky, a local artist who assumed the leadership of Friends of McCarren Park in August 1988, sought to make the organization more racially inclusive and to incorporate the wishes of the wider community over the future of the park, in general, and the pool, in particular. Yampolsky concluded that the whites of the area wanted to shrink the architecturally magnificent pool in order to prevent minority populations from using it (Friends of McCarren Park, 1989). In the beginning of 1989, the Friends of McCarren Park inaugurated a campaign to preserve the two wings of the existing bathhouse slated for demolition because they had historic and architectural value. Architect Bolek Ryzinski surveyed the pool and concluded that existing buildings were structurally sound and reparable without much effort and added that any attempt of demolition would represent an arduous, complicated, and costly process (Ryzinski, 1988). Architectural historian Andrew Dolkart wrote to parks commissioner Henry Stern and stated that "the McCarren Park Pool is one of the most significant buildings in Brooklyn that have been built during the Great Depression" (Dolkart, 1989). Architect Michael Kwartler argued that to "demolish such a facility only to rebuild a smaller version of the same facility defies common sense particularly at a time when the City's budget is strained by the pressing needs of its less fortunate citizens" (Kwartler, 1989). Halina Rosenthal (1989), president of the Friends of the Upper East Side Historic Districts wrote that "not only will the demolition of the pavilion's wings will be extremely costly, but casting away a mountain of debris will be a Sisyphus-like job and escalate the costs even further." Architect Robert A. M. Stern stated that "this was a social vision that was, for once, married to a great architectural statement" (Dunlap, 1989). In the spring of 1989, Commissioner of Parks and Recreation Henry J. Stern who felt that there was a "community consensus in favor of its demolition" urged Mayor Koch to take a position on the matter (Stern, 1989). Koch did not. Instead he became increasingly busy with his floundering campaign for a fourth term. In September of 1989, Koch lost in the Democratic primary against David Dinkins who went on to defeat Republican Rudolph Giuliani in the general election and become mayor. Meanwhile a faction hostile to Yampolsky's ideas deposed her from the leadership of the Friends of McCarren Park. She went on to found an alternative organization, the Independent Friends of McCarren Park (1989). The 
new leadership of the Friends of McCarren Park supported the decision of the community board to reduce the size of the pool and contended that race was not an issue in this decision. Mildred Trudy, an African American educator and member of the community board, objected to the reduction of the pool size and stated that "the pool will be so small that they could justifiably say to Latinos and African-Americans: 'It's full already. You can't get in'." Luis Garden Acosta who was in charge of El Puente, a Latino youth organization in Williamsburg argued that "this issue is not largeness or smallness, but whether a large pool would be a magnet for Latino and African-American youth" (Brozan, 1990).

In 1990, the Landmarks Preservation Commission held hearings on the question of granting all WPA pools landmark status. Many people from the community argued for granting landmark status to McCarren Pool, though members of Community Board 1 testified against it. Prominent New Yorkers such as Spike Lee, Eddie Murphy, and Geraldo Rivera wrote letters supporting preservation (Brozan, 1990; Horak, 2007). Neighborhood groups also held rallies for and against preservation. The Landmarks Preservation Commission did not rule on the issue (Todd, 1990). Besides the controversial nature of any definitive decision, the Dinkins Administration faced severe budgetary problems and projects such as the rebuilding of the McCarren Pool were shelved.

\section{The McCarren Pool as a Multi-use Alternative Space}

After it was shut down, the McCarren Pool became what architects and city planners have labeled as "wastelands," "derelict areas," "Dead Zones," "No Man's Land," and the like (Doron, 2000). The pool was fenced up and signs with the message "Danger Keep Out" were placed around it (Figures 3-5). Local residents who wanted the pool demolished insisted that the pool was an "obsolete" structure beyond repair. In fact, whenever they discovered that scavengers had removed pipes and metal fixtures or that a small fire had erupted inside the pool, they were elated because the pool had become even more obsolete. What they did not realize was that the pool was such a sturdy structure that it would take much more to destroy it. Many local residents also used the term abandoned to describe the pool despite the fact that there were always people inside it (Ethnographic Research, 1996-1998 and 2002).

In the two decades after its closure, the McCarren Pool functioned as a multi-use alternative space; Multi-use because different groups of people used the space for different purposes and alternative because the space was divorced from its previous uses as a government-operated swimming pool and usually did not conform to mainstream public or private spatial practices. Anyone could enter the pool area because its fences were flimsy and easily subdued and the local police did not patrol the pool with regularity. Generations of homeless people lived in the pool between 1983 and 2005. In the early years, the majority of these homeless were white. However, by the early 1990s they were mostly Black and Latino. Graffiti writers represented the most racially diverse group with painters from many parts of the city, including Greenpoint. Drug dealers and drug users were mostly white. Teenagers frequenting the pool were mostly from Greenpoint and white. Occasional visitors were of various racial backgrounds. Most of these populations used the pool with minimal interference. This changed in the mid-1990s because the Rudolph Giuliani Administration (1994-2001) implemented a radical version of spatial regulation (Chronopoulos, 2011) and this included raids into "abandoned" spaces such as the McCarren Pool. Homeless people adapted to aggressive policing and entered or exited the pool structure from spots that were not as obvious. Other users of the pool became more careful as well (Ethnographic Research, 1996-1998 and 2002).

Many of the homeless people who began frequenting Williamsburg and Greenpoint in 1995 had lived in Midtown Manhattan for most of the 1980s and early 1990s. They preferred Midtown Manhattan because it was near many facilities such as soup kitchens and because many 


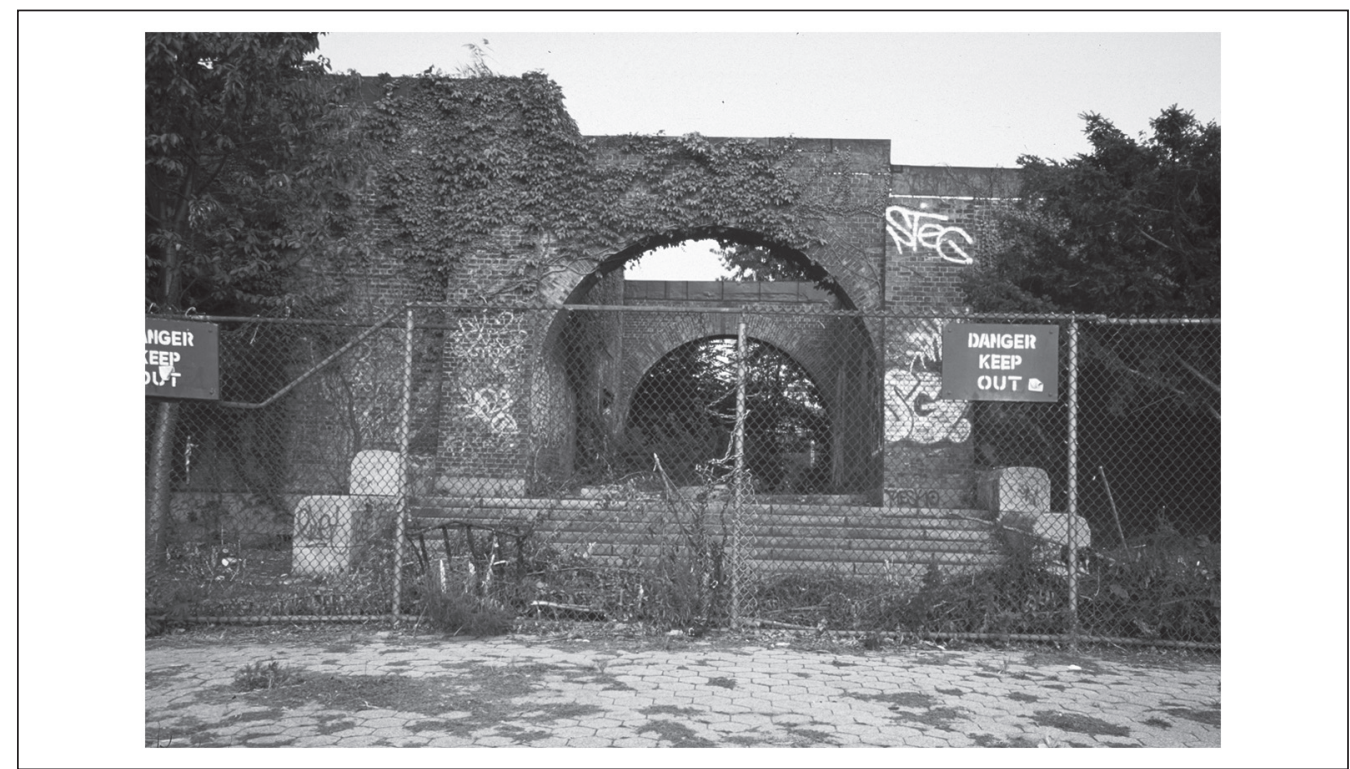

Figure 3. South wing arches, McCarren Park (2002). The "Danger Keep Out" signs gave a misleading impression about the structure. Some people thought that this was an abandoned power plant. Source: Author.

passersby gave them spare change. Having lived in Midtown for a long time, these homeless had established networks with local storekeepers who would sometimes pay them to do odd jobs (Ethnographic Research, 1996-1998).

In the mid-1990s, many homeless were forced to move from their usual locations in Midtown Manhattan by the police. Some of them escaped to other boroughs of the city such as Brooklyn, Queens, and the Bronx. The Northside of Williamsburg became an attractive destination because there were many places to stay and because people there appeared to be more tolerant. Some of the homeless also discovered McCarren Park and its pool area where they would sometimes stay (Ethnographic Research, 1996-1998 and 2002).

Older residents of the pool, who preceded the mid-1990s wave, fondly remembered the years before Giuliani and zero-tolerance policing. It was not uncommon for tens of homeless people to gather in small groups around small fires at night and play cards, eat or drink, and in general, hang out. These homeless shared the space with a few heroin users who used the pool as a shooting gallery, and drug dealers who sometimes used the pool to sell marijuana or heroin. During the day, graffiti writers went to the pool to paint large pieces, teenagers and skateboarders used the pool for recreation, and curious visitors would also enter the pool to see what was happening. One of the most impressive sights inside the pool was that almost every vertical surface had been painted by graffiti artists and some of the large pieces were exceptional (Figure 6). After 1995, with the exception of the homeless, the number of people using the pool declined because of police interventions and all kinds of people, including graffiti writers, had to operate more clandestinely. The homeless people that I met continued to stay in the pool sometimes after 1995, but they tried not to attract attention and had diversified the locations where they hung out (Figure 7). They no longer started small fires at night, avoided sleeping in the open, and moved on after a few nights to another place. Whenever too many people started to frequent the pool or when a graffiti writer painted something new on the front of the 


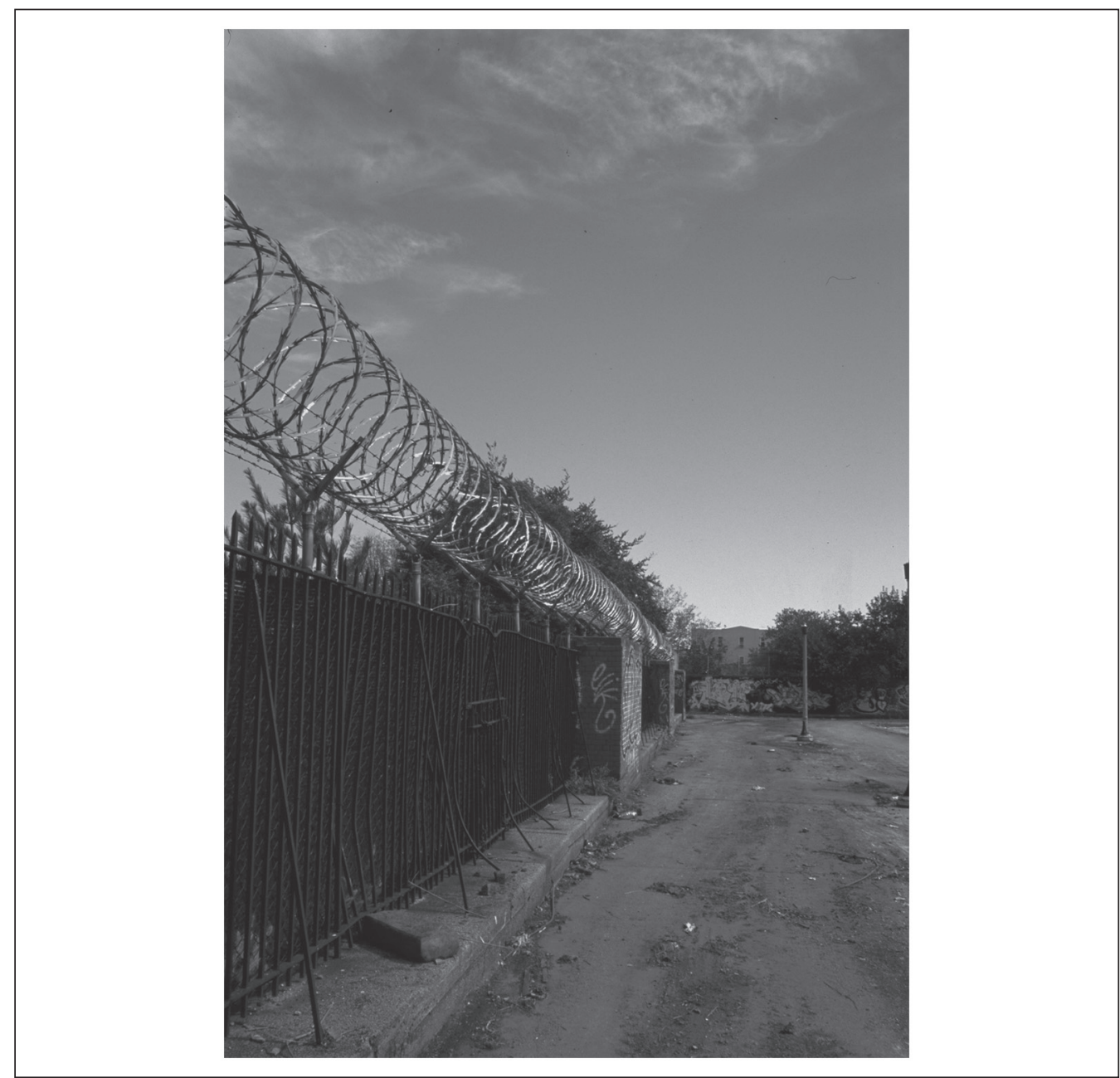

Figure 4. Fortifications outside McCarren Park (2002), showing the coexistence of fencing from different eras. Various types of fortification from different eras coexisted.

Source: Author.

structure, many homeless people moved away for a while. Although the police had been focusing on graffiti writers (Figure 8), they also routed homeless people if they encountered them inside the pool (Ethnographic Research, 1996-1998 and 2002).

The McCarren Pool functioned as a place where people sold and used narcotics although not as extensively as some area residents thought. Many people argued that junkies had used the pool to shoot heroin. Discarded drug paraphernalia inside the pool supported this claim and the homeless described this activity. Still the supply of heroin was not reliable in Greenpoint and whenever there was a shortage, many users relocated to the Southside of Williamsburg or to the Lower East Side (Ethnographic Research 1996-1998 and 2002). The McCarren Pool never became a crack house either. This can be attributed to a number of factors, including the fact that the white drug dealers who dominated Greenpoint and the Northside kept away from crack, some organized crime entities went after operators selling crack in the area, and the Puerto Rican dealers of the Southside insisted on trading heroin and cocaine (Ethnographic Research, 1996-1998 and 


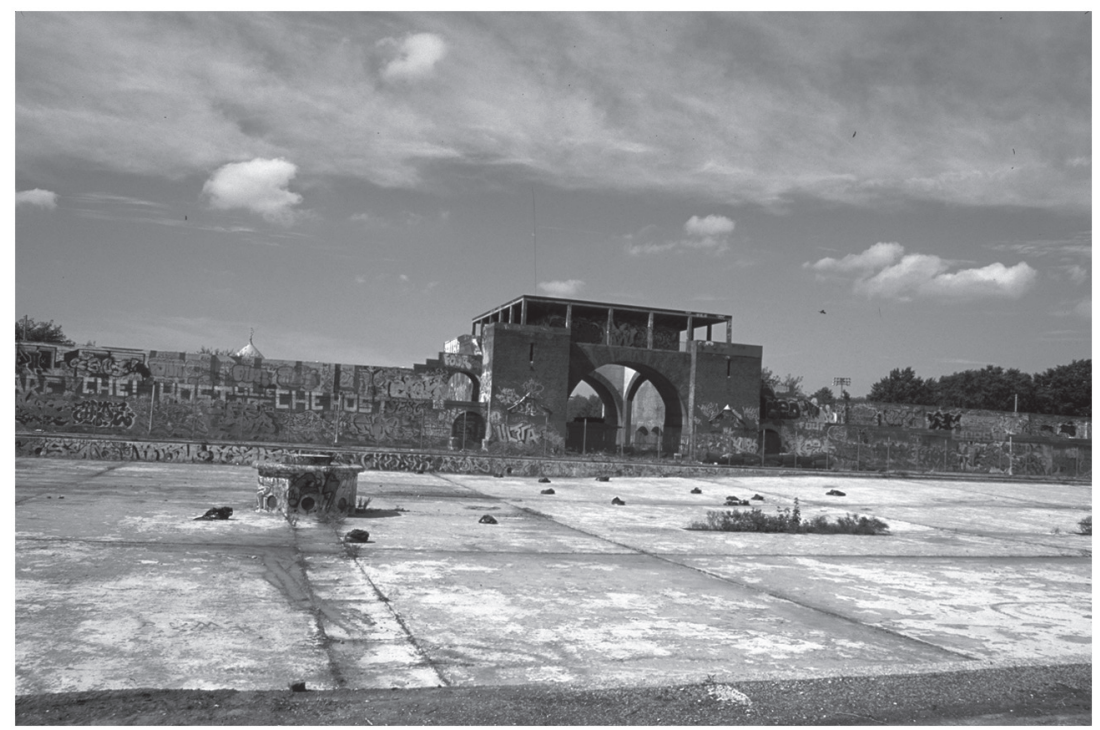

Figure 5. The sizable main area of the pool, McCarren Park (2002). Homeless people would hang out in groups throughout this area after the pool's closure in 1983.

Source: Author.

2002; Curtis, 2003). The crack trade had a presence in northern Greenpoint in the early 1990s, but by then it was too late for the drug to predominate because it had become less fashionable and because the city administration had reorganized the police into a more efficient organization that went after drug dealers (Ethnographic Research, 2002).

Between 1983 and 2005, the McCarren Pool became what Tim Cresswell (1996) has defined as a transgressive space. Cresswell argues that spaces of transgression are ideological constructs that are used to juxtapose normative spaces with unacceptable ones. Transgressive spaces and their users are vulnerable because they exist at the margins of society. Many residents of Greenpoint and the Northside subscribed to this view and considered the McCarren Pool to have become a "cesspool" frequented by "undesirables." And yet what was happening inside the structure of the McCarren Pool hinted at the "possibility of a less authoritarian public space more reflective of polyvocal points of view" (Cresswell, 1996, p. 166). Graffiti writers, homeless people, junkies, and teenagers used the space without seeking to exclude each other. This was the only time in the pool's history that diverse groups of people from various socioeconomic backgrounds coexisted peacefully inside its structures. Despite police crackdowns, the McCarren Pool continued to be used throughout the 1990s and the early 2000s. After 1999, the police began to neglect the pool area once again, so the numbers of people frequenting it increased. Still, they would try to avoid detection, since patrol cars would sometimes stop and check, if they observed movement by many people inside the pool (Ethnographic Research, 2002).

\section{The McCarren Pool as a Neoliberal Space}

In September 2005, choreographer Noémie Lafrance staged "Agora," a site-specific dance performance at the McCarren Pool. Before staging the performance, the parks department 


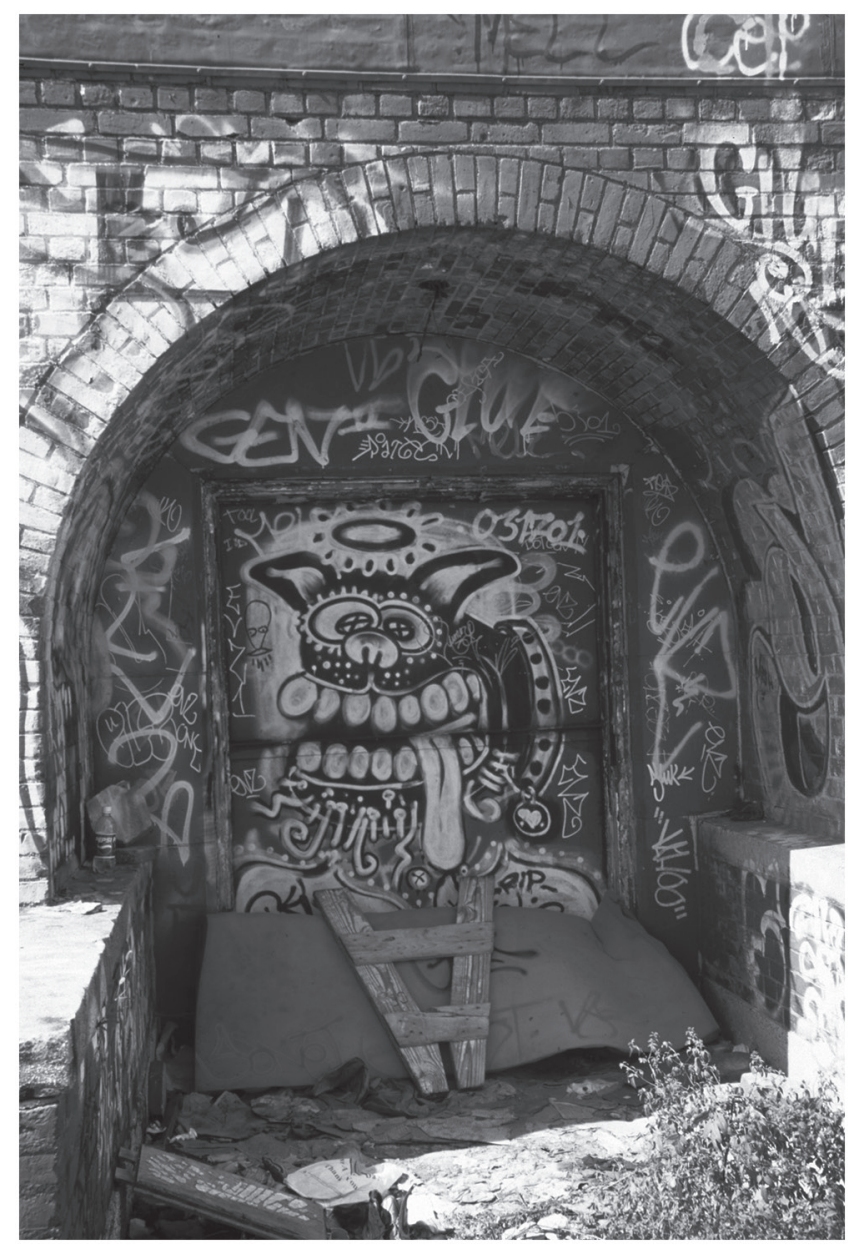

Figure 6. McCarren Park (2002). A graffiti piece in the pool.

Source: Author.

requested a fee of $\$ 250,000$ to clean and prepare the pool. LaFrance's experimental arts organization Sens, raised \$50,000 through grants. Concert promoter Live Nation, which was a Clear Channel Communications spin-off, donated \$250,000 ("Noémie Lafrance/Sens Presents Agora," 2005). “Agora” was performed for 10 evenings with tickets costing \$23 if bought in advance and \$25 at the door. Lafrance promoted the event as a "re-inauguration of the historical site" and promised to work with the parks department to restore the pool and its surrounding structures (Sisario, 2006).

Though not clear at the time, the success of "Agora" contributed in the transformation of the McCarren Pool into a neoliberal performance space. In 2006, the city administration embarked on a public-private partnership with Live Nation, which organized a series of concerts priced from $\$ 29.50$ to $\$ 39.50$. This angered many people in the community who resented the turning over of the pool to a private corporation. LaFrance, who had to reschedule "Agora II" because Live Nation took away her performance date, stated: "Clear Channel is stepping on our toes.... 


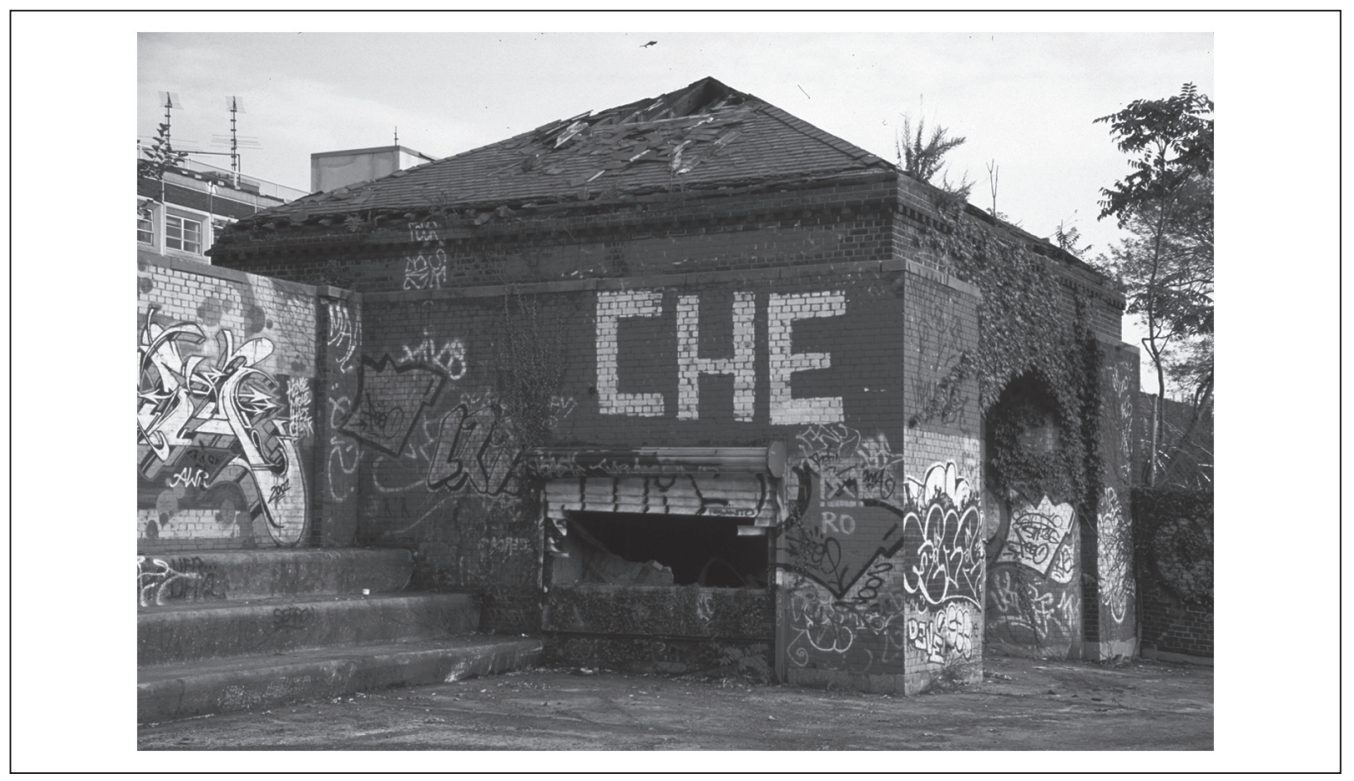

Figure 7. McCarren Park (2002). Some of the older pool residents lived in this structure of the pool. Its interior had been damaged by fire.

Source: Author.

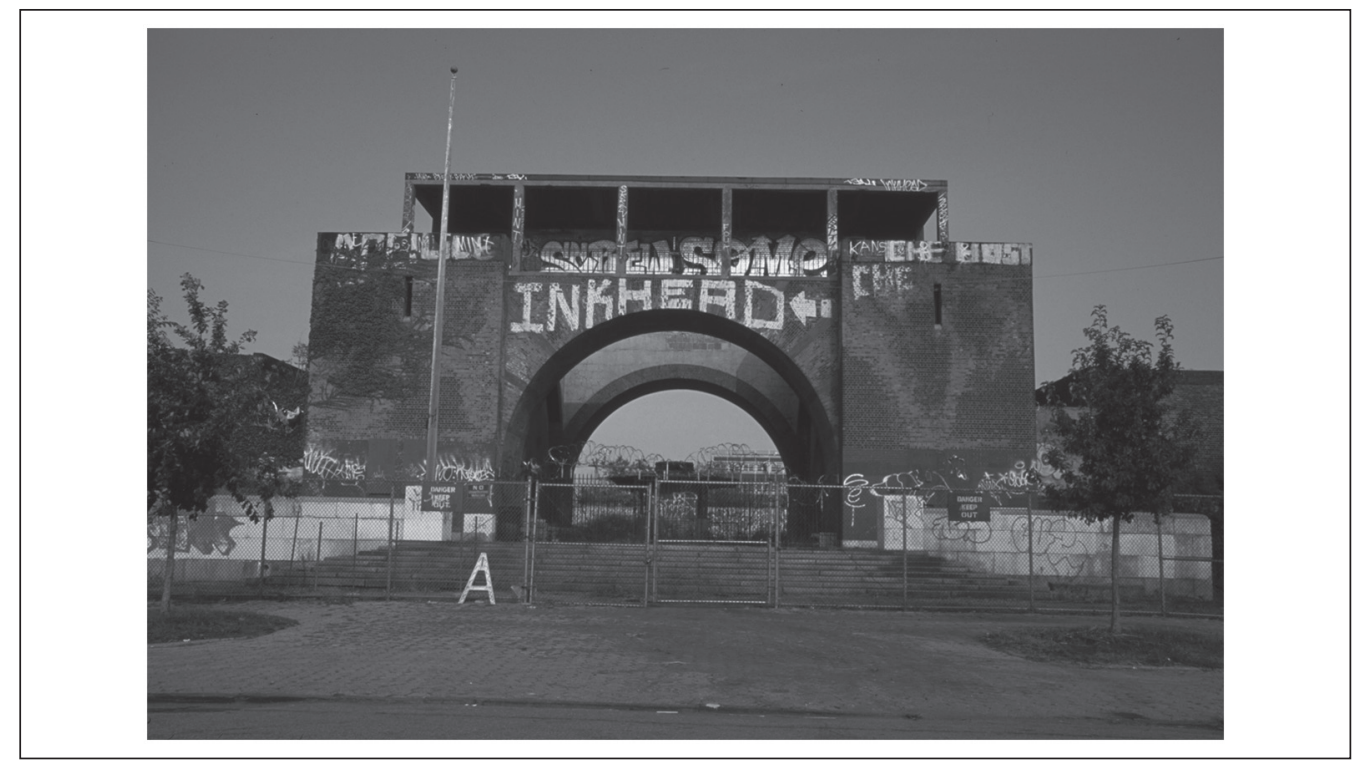

Figure 8. The pool entrance as seen from Lorimer Street, McCarren Park (2002). The police would monitor the pool whenever new graffiti pieces appeared in the façade. Source: Author.

The Parks Department is selling our parks as real estate to corporate America." Katie Naplatarski, a member of a local children's advocacy group called Park Moms, declared "I'm concerned about a private corporation making use of public space without input from the community, 
without the community even knowing" (Heinlein, 2006). In an e-mail to the blog Gothamist, a writer contended:

This pisses me off. Clear Channel paid off the parks department to take over the McCarren Park pool site for a series of 6-10 \$30 concerts $(+\$ 14$ service fee) this summer. They "improve the infrastructure", i.e. whitewash all the fierce precious 1980s graffiti (much already gone thanks to those dance performances, sorry dance people but that wasn't cool). (Carlson, 2006)

After this public outcry, the city administration also allowed JellyNYC, a local Brooklyn organization, to organize a series of free "pool parties." Most of these events were music concerts, though films and other performances were also staged. The JellyNYC events required heavy corporate branding, because without corporate sponsorship the events could not be free. Performances and movies continued in the pool until the summer of 2008 (Ethnographic Research, 2010).

These pool events had their own logic of exclusion. The great majority of the concerts featured indie rock artists. The expensive concerts presented by Live Nation excluded people who could not afford them. The free events presented by JellyNYC excluded people who preferred music other than indie rock. All the concerts, free and unfree, catered to young people who had been gentrifying Williamsburg and Greenpoint (see Curran, 2004, 2007; DeSena, 2009). There was no effort to incorporate the musical preferences of other populations living nearby the pool, because Live Nation and JellyNYC did not specialize in these other types of music and because there were questions over the profitability or corporate sponsorship of such events (Ethnographic Research, 2010).

This alliance of cultural entrepreneurs and the city government was part of a comprehensive remaking of Greenpoint and Williamsburg. In 2005, the Michael Bloomberg Administration, which has been characterized as staunchly neoliberal (Brash, 2011; Chronopoulos, 2012), rezoned Greenpoint and Williamsburg in order to entice private developers to build luxury condominiums. The rezoning aimed at encouraging massive developments in land where such building was previously prohibited (Figure 9). As part of the rezoning, the city administration promised to develop new parks, upgrade existing public facilities, and make previously closed-off portions of the waterfront accessible to the public (City Planning Commission, City of New York, 2005). This new stage also marked the cooperation of the city government with successful and established cultural organizations in order to create a cultural infrastructure that could transform the area into a mainstream cultural destination.

\section{Conclusion}

In 2012, a new stage will commence at McCarren Pool. Through adaptive use, the site is slated to reopen and function as a swimming pool, a community center, a concert venue, a gymnasium, and a winter ice skating ring. The McCarren Pool has the potential of becoming a multi-use quasi-public space. Although affluent newcomers will be a factor, the majority of the people who will be using the pool are going to be middle and low income. For example, right next to the McCarren Pool, there is a junior high school with about 477 students. The overwhelming majority of these students are Latinos and African Americans. Despite the gentrification of the area, these students live with their families near the pool and it is more than certain that they will use the pool for swimming once it reopens. They will predictably share the pool with many different groups of people, including white families and their children.

A sanitized history of the McCarren Pool will not serve most of these groups well once the site is restored. As the experience of the 2005-2008 period demonstrates, the tendency to exclude 


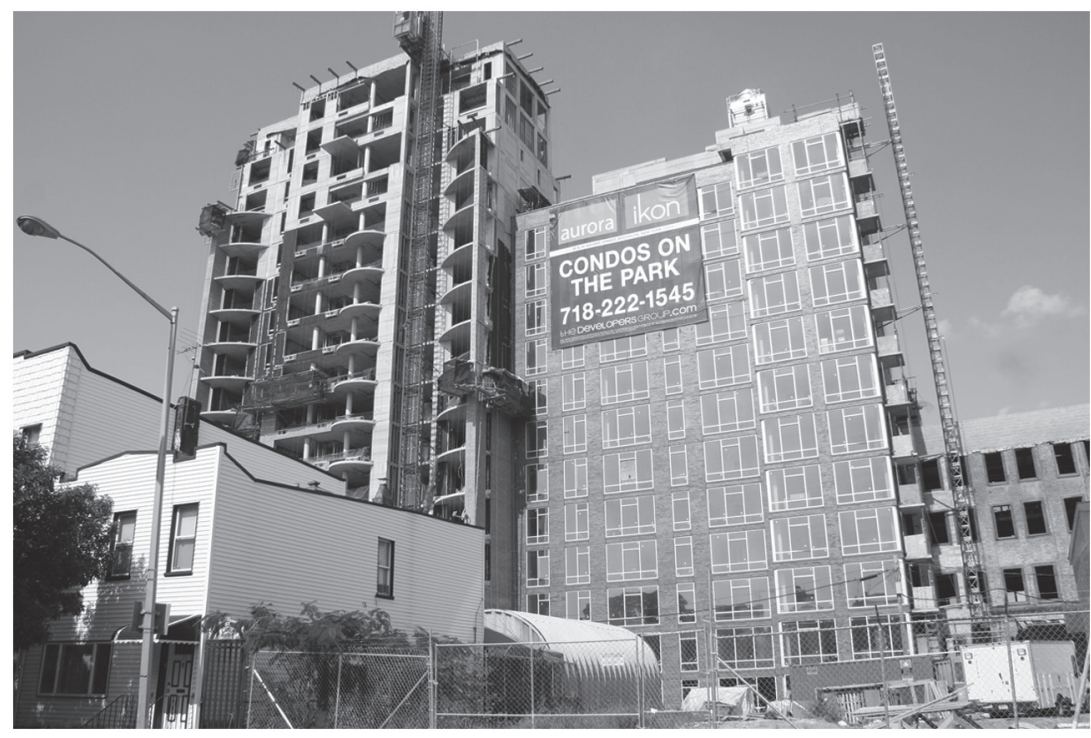

Figure 9. Luxury condominiums built next to McCarren Park (2006).

Source: Author.

various groups of people from this public structure has persisted. Though this period was short and temporary, the fact that social exclusion based on a combination of market capitalism and popular culture occurred, shows that residents of Greenpoint and Williamsburg need to guard this facility and keep it open and public. The restored McCarren Pool has the potential of becoming an inclusive multi-use facility and a comprehensive history of the pool and its former users can help future users understand the democratic potential of the site and the dangers that surround it.

\section{Acknowledgments}

The author would like to thank the staff members of the Municipal Archives of the City of New York for their assistance.

\section{Declaration of Conflicting Interests}

The author declared no potential conflicts of interest with respect to the research, authorship, and/or publication of this article.

\section{Funding}

The author received no financial support for the research, authorship, and/or publication of this article.

\section{Note}

1. This article is partly based on ethnographic research. Influenced by the way that cultural anthropologists, human geographers, social historians, and urban sociologists have been conducting research, I began to design and implement ethnographic and archival projects in New York City neighborhoods in the mid1990s. The McCarren Pool Project was part of ethnographic research that examined the gentrification of Williamsburg and Greenpoint in Brooklyn. My methodology included spatial analysis accompanied by the reading and making of maps; interviews, conversations, and observations recorded in notebooks; the sequential photography of these neighborhoods and the subsequent cataloging and studying of the 
photographs; and the reading of primary and secondary writings about these neighborhoods in libraries and archives. The ethnographic findings of this article are based on firsthand observations of the use of space in and around the McCarren Pool, the photography of the built environment in Greenpoint and Williamsburg, and short snowball interviews with a diverse sample of informers.

\section{References}

Braiterman, M. (1989, February 4). Letter to Phyllis Yampolsky. Koch Administration Archives, Departmental Correspondence, Box 226, Folder 9, Municipal Archives of the City of New York.

Brash, J. (2011). Bloomberg's New York: Class and governance in the luxury city. Athens: University of Georgia Press.

Brozan, N. (1990, July 30). A crumbling pool divides a neighborhood. The New York Times, p. B1.

Carlson, J. (2006, May 25). McCarren Pool controversy. Gothamist. Retrieved from http://gothamist. com/2006/05/25/mccarren.php

Caro, R. (1974). The power broker: Robert Moses and the fall of New York. New York, NY: Random House.

Celona, L. (1986, March 23). Greenpoint park plans offered. Daily News, p. B1.

Chronopoulos, T. (2011). Spatial regulation in New York City: From urban renewal to zero tolerance. New York, NY: Routledge.

Chronopoulos, T. (2012). Congestion Pricing: The Political Viability of a Neoliberal Spatial Mobility Proposal in Stockholm, London, and New York City. Urban Research and Practice, 5, 187-208.

City Planning Commission, City of New York. (2005, March 4). Greenpoint-Williamsburg rezoning: Final environmental impact statement. New York, NY: Author.

Cresswell, T. (1996). In placelout of place: Geography, ideology, and transgression. Minneapolis: University of Minnesota Press.

Curran, W. (2004). Gentrification and the nature of work: Exploring the links in Williamsburg, Brooklyn. Environment and Planning A, 36, 1243-1258.

Curran, W. (2007). "From the frying pan to the oven": Gentrification and the experience of industrial displacement in Williamsburg, Brooklyn. Urban Studies, 44, 1427-1440.

Curtis, R. (2003). Crack cocaine and heroin: Drug eras in Williamsburg, Brooklyn, 1960-2000s. Addiction Research \& Theory, 11, 47-63.

Davis, G. J. (1978, February 24). Draft audit report: Employee productivity and related matters in the Department of Parks and Recreation. Koch Administration Archives, Departmental Correspondence, Box 225, Folder 5, Municipal Archives of the City of New York.

Davis, G. J. (1979, April 30). Bi-weekly report on departmental activities. Koch Administration Archives, Departmental Correspondence, Box 225, Folder 8, Municipal Archives of the City of New York.

Davis, G. J. (1980a, January 4). Department of Parks and Recreation capital budget and CD VI submissions-Outlook and priority considerations for fiscal year 1981. Letter to Robert F. Wagner, Jr. and James R. Brigham. Koch Administration Archives, Departmental Correspondence, Box 225, Folder 9, Municipal Archives of the City of New York.

Davis, G. J. (1980b, September 22). Briefing for EIK meeting with Times. Letter to Edward I. Koch. Koch Administration Archives, Departmental Correspondence, Box 225, Folder 10, Municipal Archives of the City of New York.

de Certeau, M. (1984). The practice of everyday life. Berkeley: University of California Press.

DeSena, J. N. (2009). Gentrification and inequality in Brooklyn: The new kids in the block. Lanham, MD: Lexington Books.

Dolkart, A. S. (1989, January 13). Letter to Henry J. Stern. Koch Administration Archives, Departmental Correspondence, Box 226, Folder 10, Municipal Archives of the City of New York.

Doron, G. M. (2000). The dead zone and the architecture of transgression. City, 4, 247-263.

Dunlap, D. W. (1989, March 6). Old Bathhouse defended as Brooklyn landmark. The New York Times, p. B1. 
Friends of McCarren Park. (1987, May 6). Meeting minutes. Koch Administration Archives, Departmental Correspondence, Box 226, Folder 9, Municipal Archives of the City of New York.

Friends of McCarren Park. (1989, February 7). Issue: Pending demolition of McCarren Park Pool Bathhouses. Spring '89. Koch Administration Archives, Departmental Correspondence, Box 226, Folder 9, Municipal Archives of the City of New York.

Gilbert, T. (2007a, September 8). The real story of an old pool. The Brooklyn Paper. Retrieved from http:// www.brooklynpaper.com/stories/30/35/30_35oldpool.html

Gilbert, T. (2007b, September 22). The old pool story, part II. The Brooklyn Paper. Retrieved from http:// www.brooklynpaper.com/stories/30/37/30_37poolstory.html

Goodwin, M. (1980, October 14). Parks plagued by a shortage of good help. The New York Times, p. B1.

Gutman, M. (2007). Equipping the public realm: Rethinking Robert Moses and recreation. In H. Ballon \& K. T. Jackson (Eds.), Robert Moses and the modern city: The transformation of New York (pp. 72-85). New York, NY: W. W. Norton.

Hayden, D. (1995). The power of place: Urban landscapes as public history. Cambridge: MIT Press.

Heinlein, S. (2006, July). Water fight at McCarren Park Pool. The Brooklyn Rail. Retrieved from http:// brooklynrail.org/2006/07/local/water-fight-mccarren

Horak, K. E. (2007). McCarren Play Center, designation list 394 LP-2244. Washington, DC: Landmarks Preservation Commission.

Independent Friends of McCarren Park. (1989, July 7). Koch Administration Archives, Departmental Correspondence, Box 226, Folder 10, Municipal Archives of the City of New York.

Kayden, J. (2000). Privately owned public space: The New York City experience. New York, NY: John Wiley.

Kwartler, M. (1989, January 16). Letter to Phyllis Yampolsky. Edward I. Koch Administration Archives, Departmental Correspondence, Box 226, Folder 9, Municipal Archives of the City of New York.

Marcus, B. L. (2006). Last one in: Community, conflict and the preservation of McCarren Park Pool (Unpublished master's thesis). Columbia University, New York.

Melosi, M. V. (1981). Garbage in the cities: Refuse, reform, and the environment, 1880-1980. College Station: Texas A\&M Press.

Mendell, J. (1986, April 15). McCarren Park sports complex: Community board approves plan for Olympic size pool. North Brooklyn Community News, p. 1.

New York City Bureau of Health Statistics and Analysis. (1974). Vital statistics by health areas and health center districts. New York, NY: Department of Health.

New York City Planning Commission. (1969). Plan for New York City 1969: A proposal. 3: Brooklyn. New York, NY: City of New York.

Noémie Lafrance/Sens Presents Agora. (2005, September 13-18, 20-24). Press release.

Partnerships for Parks. (2007). McCarren Park Pool, PlaNYC survey results. New York, NY: Author.

Quindlen, A. (1980, October 13). New York City park system stands as a tattered remnant of its past. The New York Times, p. A1.

Rosenthal, H. (1989, January 18). Letter to Henry J. Stern. Edward I. Koch Administration Archives, Departmental Correspondence, Box 226, Folder 9, Municipal Archives of the City of New York.

Ryzinski, B. (1988, December 14). Reconstruction of the swimming pool complex at McCarren Park in Greenpoint, N.Y. Letter to Phyllis Yampolsky. Edward I. Koch Administration Archives, Departmental Correspondence, Box 226, Folder 9, Municipal Archives of the City of New York.

Sisario, B. (2006, June 30). Dive in, the music's fine: Rock moves outdoors. The New York Times, p. E1.

Stern, H. J. (1985a, April 24). Pool safety and repairs. Letter to Stanley Brezenoff. Koch Administration Archives, Departmental Correspondence, Box 225A, Folder 8, Municipal Archives of the City of New York.

Stern, H. J. (1985b, August 23). Size of rebuilt pools. Letter to Stanley Brezenoff. Koch Administration Archives, Departmental Correspondence, Box 225A, Folder 9, Municipal Archives of the City of New York. 
Stern, H. J. (1985c, September 24). Swimming pool reconstruction. Letter to Stanley Brezenoff. Koch Administration Archives, Departmental Correspondence, Box 225A, Folder 9, Municipal Archives of the City of New York.

Stern, H. J. (1989, March 10). McCarren Bathhouse preservation-Correspondence from Phyllis Yampolsky. Letter to Ed Koch. Edward I. Koch Administration Archives, Departmental Correspondence, Box 226, Folder 10, Municipal Archives of the City of New York.

Susser, I. (1982). Norman street: Poverty and politics in an urban neighborhood. New York, NY: Oxford University Press.

Todd, D. F. M. (1990, March 29). March monthly report. Letter to Norman Steisel. Koch Administration Archives, Departmental Correspondence, Box 12, Folder 102, Municipal Archives of the City of New York.

Tung, A. M. (2001). Preserving the world's great cities: The destruction and renewal of the historic metropolis. New York, NY: Three Rivers Press.

Wilder, C. S. (2000). A covenant with color: Race and social power in Brooklyn. New York, NY: Columbia University Press.

Wiltse, J. (2007). Contested waters: A social history of swimming pools in America. Chapel Hill: The University of North Carolina Press.

Yampolsky, P. (1989, February 7). Issue: Pending demolition of McCarren Park Pool Bathhouses Spring '89. Koch Administration Archives, Departmental Correspondence, Box 226, Folder 9, Municipal Archives of the City of New York.

\section{Author Biography}

Themis Chronopoulos is a Lecturer in American Studies at the University of East Anglia, Norwich, UK. His fields of specialization include urban history, American studies, race and ethnicity, popular culture, public policy, world cities, and human geography. He is the author of the book Spatial Regulation in New York City: From Urban Renewal to Zero Tolerance (Routledge, 2011). His current research projects cover the topics of social inequality, urban governance, municipal services, immigration, neoliberal urbanization, and spatial mobility. His website is at http://themis.slass.org/ 